\title{
INTEREST RATE PASS-THROUGH ESTIMATES FROM ERROR CORRECTION MODELS ECM
}

\author{
Le Phan Thi Dieu Thao', Nguyen Thi Thu Trang ${ }^{2}$ \\ ${ }^{1}$ Banking University Ho Chi Minh City \\ ${ }^{2}$ OceanBank \\ Email: dieuthaodhnh@gmail.com
}

(Received:09/12/2014; Revised: 26/03/2015; Accepted: 19/05/2015)

\begin{abstract}
This paper examines the degree of pass-through and adjustment speed of retail interest rates in response to changes in monetary policy rates in commercial banks of Viet Nam during the period 07/2004 to 06/2014. The results show that the degree of pass-through of retail interest rates is incomplete but high (0.7-0.93). The adjustment speed of money market rates \& retail interest rates is relatively slow. It takes from 3 to 6 months for money market rates \& retail interest rates to be adjusted to long-term equilibrium, except 1 month VNIBOR. 1 month VNIBOR is sensitive to changes of discount rate \& refinancing rate in short-term, contrary to 3 month VNIBOR. The degree of pass-through from market rates to retail interest rates is fairly high in the long-term but low in the short-term. The degree of pass-through is different between various retail interest rates. Specifically, the degree of pass-through of deposit rates is higher than that of lending rates both in the short-term \& long-term.
\end{abstract}

Keywords: Interest rate pass-through, monetary policy, error correction model ECM.

\section{Introduction}

Monetary policy has an influence on economy through pass-through channels: interest rate, assets and credit channel (Mishkin,1996). Among them, interest rate is one of the most basic \& important channels mentioned a lot in economics theories.

Interest rate is not only a tool of adjusting market, but also a dynamic to give signal of government about mode of operating monetary policy. Therefore, it's very important to understand the degree of pass-through and adjustment speed of retail interest rates in response to changes in monetary policy rates. Then, the government can choose the period to adjust interest rate and degree of adjustment suitably to enhance adjustment effectiveness of monetary policy, provide a stable macroeconomic environment to develop economy both in the short term and long term.

The research of interest rate pass- through attracts much concern of experimental researchers all over the world. However, up to the $2^{\text {st }}$ quarter of 2014, there are just a few experimental research on this issue in Viet Nam. So, to study the degree of pass-through and adjustment speed of retail interest rates in response to changes in monetary policy rates is extremely essential, especially with a developing and difficult country like Viet Nam. Therefore, this is also the main reason that this paper is implemented to examine the degree of pass-through from policy rates into retail interest rates of commercial banks at Viet Nam. In particular, this paper will answer the question when policy rates change, how they will influence on the degree and adjustment speed of retail interest rates in the short-term and long-term.

\section{Literature review}

Mishkin (1996) showed that there are three basic pass-through channels of monetary 
policy such as: traditional interest rate, assets and credit channel.

Interest rate pass-through is defined as the degree and speed of changes of policy or market rates into retail banking rates (Ur Rehman, 2009). In other words, interest rate pass-through is a process where the official interest rate is transmitted to other interest rates. The central bank of a country will increase the official interest rate when the rate of inflation beyond the target band. The success of the monetary policy in stabilizing inflation and achieving inflation targets depends on the stickiness of market interest rates. An incomplete interest rate pass-through can lead to a violation of the Taylor principle and failure of monetary policy to stabilize shocks (Marotta, 2009). The nature of interest rate pass-through will determine the degree of competitiveness and the soundness of the financial system (Aydin, 2007 and Hofmann, 2002). A quicker, symmetric and complete interest rate passthrough will lead to a well functioning, competitive and efficient financial system.

The interest rate can be divided into two stages. The first stage examines the passthrough of monetary policy rates into the short term and long term market rates. The stability of the yield curve highly affects the first stage. If the yield curve remains constant over time, then the market rates is said to be proportionate. Nonetheless, any changes in the yield curve may alter the size of pass-through. The second stage examines how changes in the market rates affect bank deposit and lending rates (Ur Rehman, 2009). For the second stage of interest rate pass-through, the relationship between market rates, bank deposit and lending rates of comparable maturity can be investigated with the cost of funds approach (de Bondt, 2005).

Most of the researchers seek to study the degree and speed of adjustment of banking rates to changes in money market rates. Previous studies report that changes of retail rate into market interest rate are incomplete. These studies also find that the degree and speed of pass-through vary across countries, especially retail rates. Besides, the rates are very different across countries, which may due to the macroeconomics or other factors. Among these studies include Borio \& Fritz (1995), Cottarelli \& Kourelis (1994), Mozzami (1999), Mojon (2000), Kleimeier and Sander (2000), Donnay and Degryse (2001), Toolsema et al. (2002), Espinosa-Vega and Rebucci (2003).

According to Roelands (2012), banks tend to increase loan rates at roughly the same speed as the policy rates. However, when the policy rates fall, adjustments to loan rates are slower and incomplete. In case of rising (or falling) policy rates, however, capital and liquidity constraints cause the loan rates to increase (or decrease) higher (or lower) than the policy rates.

Ming-Hua Liu et al (2005) researched about the degree of pass-through and adjustment speed of retail interest rates in response to changes in benchmark wholesale rates in New Zealand during the period 1994 to 2004. They considered the effect of policy transparency and financial structure in the transmission mechanism.

Lim (2001), Heffernan (1997), De Bondt (2002), and Blot \& Labondance (2010) measured the efficiency of the short-term interest rate pass-through, the long-term interest rate pass-through, and the asymmetric interest rate pass-through in the interbank market. Lim's research (2001) found out incomplete interest rate pass-through between three Australian bank interest rates-bank bond rate, loan rate, and deposit rate and gave two conclusions: (i) interest rate adjustments in response to negative and positive shocks are incomplete in the short run, but complete in the long run; and (ii) banks adjust their loan and deposit rates at a faster rate during periods of loosening monetary policy than during periods of tight monetary policy.

The research of pass-through effect of monetary policy during the past years in Viet Nam has mainly investigated efficiency of monetary policy in general, but has not considered or considered little the effect of interest rate pass-through channel in passthrough mechanism of monetary policy yet. We can see typical research as bellows: Nguyen Khac Quoc Bao (2014) investigated 
about monetary policy pass-through in Viet Nam, Tran Ngoc Tho (2013) analysed monetary policy pass-through mechanism in Viet Nam approaching to SVAR model, Le \& Pfau (2008) analyzed the role of pass-through channels in Vietnam, employing the vector auto-regression approach (VAR) and analysis of impulse response function and variance decomposition.

Clearly, the research of effect of monetary policy tools, especially research of effect of policy rates to retail interest rates of commercial banks in Viet Nam is limited. We haven't found out deep and suitable research applying ECM on this issue, except research of Dinh Thi Thu Hong and Phan Dinh Manh (2013) that examined interest rate passthrough mechanism from policy rates through money market rates to retail interest rates in Viet Nam and some other emerging countries in Asia. The error correction model ECM was used to test whether the adjustment speed is symmetric or asymmetric while ECMEGARCH- $M$ model was used to check the impact of interest rate volatility, stickiness during adjustment process and leverage effect on the pass-through. The result showed that the pass-through degree from money market rate to retail interest rate was incomplete.

Generally, using ECM in empirical research on monetary policy pass-through in Viet Nam is suitable to general intendency of research. However, empirical research needs update data to have more reliable results. Moreover, domestic researchs haven't explained clearly about model structure yet. The research of Dinh Thi Thu Hong and Phan Dinh Manh (2013) used data during the period 01/1997-12/2012. But it's clear that after the year 2012, there are many changes in monetary policy governing of Viet Nam to make it suitable to international economics integration requirements. This paper is implemented to supplement idea for above mentioned issue.

\section{Data and Empirical Methodology}

\section{Methodology}

We build pass-through mechanism based on method of the approach of capital cost. This method bases on market rates to consider changes of bank retail interest rates. Consequently, the pass-through will be separated into 2 phases as below:

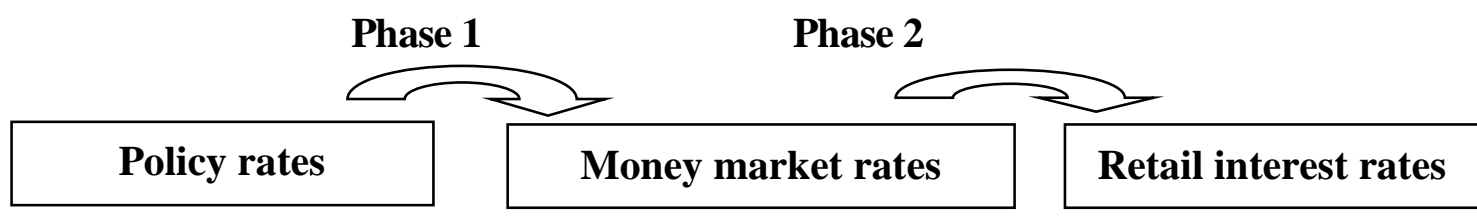

\section{Long-run pass-through}

In this paper, we examine both the longrun and short-run pass-through of monetary policy rates to various retail interest rates as well as the adjustment speed of the short-term dynamics to the longterm equilibrium relationship.

The long-term relationship between policy rates and money market rates as well as between money market rates and retail interest rates is expressed as:

$$
Y_{t}=\alpha_{0}+\alpha_{1} x_{t}+\varepsilon_{t}
$$

Where $Y_{t}$ is money market rates if $x_{t}$ is policy rates (phase 1) and retail interest rates if $\mathrm{x}_{\mathrm{t}}$ is money market rates (phase 2); $\alpha_{0}$ measures the markup; $\varepsilon_{\mathrm{t}}$ is the error term; $\alpha_{1}$ measures the degree of pass-through in the long-term. The long-run pass-through is complete if $\alpha_{1}$ is statistically not different from one.

Short-run pass-through and the mean adjustment lag.

In this paper, we estimate the degree of pass-through and the adjustment speed of money market rates (in phase 1) and retail interest rate (in phase 2) using ECM (Error Correction Model) and take lags of various pair of interest rates respectively according to VAR model (maximum lag is 12). Error Correction Model ECM is presented in equation (2):

$$
\Delta y_{t}=\beta_{0} \Delta x_{t}+\delta\left(y_{t-1}-\alpha_{0}-\alpha_{1} x_{t-1}\right)+\sum_{i=1}^{q} B_{i} \Delta x_{t-i}+\sum_{i=1}^{p} \Gamma_{i} \Delta y_{t-i}+v_{t}
$$

where $\Delta$ expresses first difference operator. $\varepsilon_{\mathrm{t}-1}=\mathrm{Y}_{\mathrm{t}-1}-\alpha_{0}-\alpha_{1} \mathrm{X}_{\mathrm{t}-1}$ denotes the 
extent of disequilibrium at time $(\mathrm{t}-1)$ and it is the residual of the long-run relationship given by Equation (1). $\mathrm{v}_{\mathrm{t}}$ is the error term. $\beta_{0}$ measures the contemporaneous or impact pass-through rate. $B_{i} \& \Gamma_{i}$ are dynamic adjustment coefficients. $\delta$ expresses the error correction adjustment speed when the rates are away from their equilibrium level. The sign of $\delta$ is expected to be negative due to the mean-reverting nature of interest rates.

The same type of equation describes the dynamics of adjustment in the policy rate $\Delta \mathrm{x}_{\mathrm{t}}$. That is the mean adjustment lag (MAL). The mean adjustment lag (MAL) of a complete passthrough for a general $\operatorname{ADL}(p, q)$ model or its equivalent ECM parameterization, can be calculated using the formula given in Hendry (1995) in the equation 3:

$$
\text { MAL }=\left(\beta_{0}-1\right) / \delta
$$

MAL is the weighted average of all lags and it is a measure of the speed with which money market rates respond to movements in policy rates (phase 1) and which retail interest rates respond to changes in money market rates (phase 2). MAL is the necessary time so that money market rates and retail interest rates (correlatively in phase 1 and phase 2) are adjusted to the long-run equilibrium level.

\section{Data}

Discount rate (TCK), refinancing rate (TCV) are represented for policy rates because adjustment of TCK, TCV is one of the main tools of governing monetary policy in Viet
Nam; inter-bank average interest rate (IB1 and IB3) is represented for money market rates due to imperfectly developing financial market in Viet Nam.

The paper uses discount rate (TCK), refinancing rate (TCV), 1 month VNIBOR (IB1), 3 month VNIBOR (IB3): Use value at the end of the month (\%/annum). Data source from official website of the state bank of Viet Nam.

Retail interest rates includes deposit rate (DR) and lending rate (LR) that take end-term average of 3 month deposits and short term lending of 6 big commercial banks of Viet Nam (\%/annum). Data source from International Financial Statistics-IFS and Stoxplus. The period of sample is 07/2004$06 / 2014$, equivalent to 120 months.

\section{Results}

\section{Unit root test}

Before implementing cointegration tests, we want to determine whether the individual interest rate series have unit roots, but their first-difference are stationary series. We test the null hypothesis of unit root against the alternative hypothesis of stationarity using the augmented DickeyFuller (ADF) and Phillips-Perron (PP) tests. The results of the stationarity tests on the individual interest rate series in Table 1 show that we cannot reject the hypothesis that all the series are unit root non-stationary at the level of the series, but stationary at the first difference.

Table 1. ADF Test and Phillips-Perron Test

\begin{tabular}{|c|l|l|l|}
\hline \multicolumn{2}{|c|}{ Series } & \multicolumn{1}{c|}{ ADF test } & \multicolumn{1}{c|}{ PP test } \\
\hline \multirow{4}{*}{ Policy rates } & TCK & $-2,703$ & $-2,213$ \\
\cline { 2 - 4 } & D(TCK) & $-5,623 * * *$ & $-8,608 * * *$ \\
\cline { 2 - 4 } & TCV & $-2,918$ & $-2,216$ \\
\cline { 2 - 4 } Money market rates & D(TCV) & $-7,236 * * *$ & $-7,464 * * *$ \\
\hline \multirow{5}{*}{\begin{tabular}{l} 
Mon \\
\cline { 2 - 4 }
\end{tabular}} & IB1 & $-2,100$ & $-2,507$ \\
\cline { 2 - 4 } & D(IB1) & $-14,937 * * *$ & $-14,697 * * *$ \\
\cline { 2 - 4 } & IB3 & -2.475 & $-2,101$ \\
\cline { 2 - 4 } & D(IB3) & $-12,368 * * *$ & $-12,263 * * *$ \\
\hline
\end{tabular}




\begin{tabular}{|l|l|l|l|}
\hline \multicolumn{2}{|c|}{ Series } & \multicolumn{1}{c|}{ ADF test } & \multicolumn{1}{c|}{ PP test } \\
\hline \multirow{4}{*}{ Retail interest rates } & DR & $-2,037$ & $-2,289$ \\
\cline { 2 - 4 } & D(DR) & $-5,655 * * *$ & $-5,929 * * *$ \\
\cline { 2 - 4 } & LR & $-2,155$ & $-2,379$ \\
\cline { 2 - 4 } & D(LR) & $-5,679 * * *$ & $-7,301 * * *$ \\
\hline
\end{tabular}

Note: D are the first different of various interest rate series.

Null hypothesis : Interest rates have unit root (not stationary). The sign *, **, *** show that Null hypothesis is rejected correlatively at the 10\%, 5\%, 1\% level of significance. All tests have mark up and no tendency in the series.

Engle and Granger (1987) said that if linear combination of non stationary time series could be a stationary series. And these non stationary time series were considered to be cointegrated. Therefore, the result of above stationary tests is the basis to test cointegration as belows.

\section{Cointegration Test}

The results of cointegration tests are represented at Table 2 and Table 3:

Table 2. Cointegration tests between discount rates, refinancing rates and 1 month VNIBORand 3 month VNIBOR

\begin{tabular}{|l|l|l|l|l|}
\hline \multicolumn{2}{|l|}{} & \multicolumn{2}{l|}{ TCK } & \multicolumn{1}{l|}{ TCV } \\
\cline { 2 - 5 } & ADF & PP & ADF & PP \\
\hline IB1 & $-2,467 * *$ & $-3,845 * * *$ & $-2,411 * *$ & $-3,823 * * *$ \\
\hline IB3 & $-2,026 * *$ & $-3,697 * * *$ & $-2,536 * *$ & $-3,634 * * *$ \\
\hline
\end{tabular}

Table 3.Cointegration tests between 1 month VNIBOR, 3 month VNIBOR and deposit rate and lending rate

\begin{tabular}{|l|l|l|l|l|}
\hline \multirow{2}{*}{} & \multicolumn{2}{|l|}{ IB1 } & \multicolumn{1}{l|}{ IB3 } \\
\cline { 2 - 5 } & ADF & PP & ADF & PP \\
\hline DR & $-3,977 * * *$ & $-6,141 * * *$ & $-6,102 * * *$ & $-6,208 * * *$ \\
\hline LR & $-4,128 * * *$ & $-6,325 * * *$ & $-5,648 * * *$ & $-5,765 * * *$ \\
\hline
\end{tabular}

Note: Null hypothesis: There is unit root between 2 series of rates (There is no cointegration relationship between two series). The sign *, **, *** show that Null hypothesis is rejected correlatively at the 10\%, 5\%, $1 \%$ level of significance. All tests have no mark up and no tendency in the series.

Cointegration tests at Table 2 and Table 3 show that: (i) There are cointegration relationships between discount rate, refinancing rate and 1 month VNIBOR, 3 month VNIBOR at the 5\% level of significance according to ADF test and at the $1 \%$ level of significance according to PhillipsPerron test; (ii) there are cointegration relationships between money market rates (1 month VNIBOR \& 3 month VNIBOR) and retail interest rates (deposit rate and lending rate) at the $1 \%$ level of significance.

From the result of unit root test and cointegration test, we use error correction model (ECM) to analyse the pass-through in the short run and OLS model to consider the pass-through in the long run.

\section{Results}

Table 4 showes the result of passthrough from policy rates to money market rates

Table 4. The pass-through from policy rates to money market rates

\begin{tabular}{|c|c|c|c|c|c|c|c|c|}
\hline & \multicolumn{4}{|c|}{ TCK } & \multicolumn{4}{|c|}{ TCV } \\
\hline & \multicolumn{3}{|c|}{ Short-run } & \multirow{2}{*}{$\begin{array}{c}\text { Long-run } \\
\alpha_{1} \\
\end{array}$} & \multicolumn{3}{|c|}{ Short-run } & \multirow{2}{*}{$\begin{array}{c}\text { Long-run } \\
\alpha_{1}\end{array}$} \\
\hline & $\beta o$ & $\delta$ & MAL & & $\beta o$ & $\delta$ & MAL & \\
\hline IB1 & 0,917 & $-0,208$ & 0,399 & 0,840 & 1,003 & $-0,217$ & 0,014 & 0,869 \\
\hline IB3 & 0,373 & $-0,096$ & 6,531 & 0,778 & 0,425 & $-0,091$ & 6,319 & 0,809 \\
\hline
\end{tabular}


The pass-through from discount rates to 1 month VNIBOR and 3 month VNIBOR

In the long-run, the degree of passthrough from discount rate to 1 month VNIBOR and 3 month VNIBOR is respectively high (0.84) and (0.78). That means 1 month VNIBOR and 3 month VNIBOR will change $0.84 \%, 0.78 \%$ respectively in response to changes $1 \%$ of discount rate. This shows that 1 month VNIBOR and 3 month VNIBOR is sensitive to changes of discount rate in the long-run.

In the short-run, the direct pass-through from discount rate to 1 month VNIBOR is very high (0.92). That means 1 month VNIBOR will change $0.92 \%$ in response to change $1 \%$ of discount rate, but the passthrough from discount rate to 3 month VNIBOR is just medium (0.37). Adjustment speed to long-run equilibrium is respectively low (-0.21) and (-0.10). MAL shows that it takes 0.4 month (12 days) for 1 month VNIBOR to adjust to long-run equilibrium, but more than 6 months and a haft for 3 month VNIBOR to adjust to long-run equilibrium.

The pass-through from refinancing rates to 1 month VNIBOR and 3 month VNIBOR

In the long-run, the degree of passthrough from refinancing rate to 1 month VNIBOR and 3 month VNIBOR is respectively high (0.87) and (0.81). That means 1 month VNIBOR and 3 month VNIBOR will change $0.87 \%, 0.81 \%$ respectively in response to changes $1 \%$ of refinancing rate.
In the short-run, the direct pass-through from refinancing rate to 1 month VNIBOR is complete (1.00). That means 1 month VNIBOR will change $1.00 \%$ in response to change $1 \%$ of refinancing rate, but the passthrough from refinancing rate to 3 month VNIBOR is just medium (0.43). Adjustment speed to long-run equilibrium is respectively (0.22 ) and (-0.10). MAL shows that it takes 0.01 month for 1 month VNIBOR to adjust to long-run equilibrium. That means 1 month VNIBOR will change nearly immediately when refinancing rate changes, but it takes more than 6 months for 3 month VNIBOR to adjust to long-run equilibrium.

In brief, 1 month VNIBOR is very sensitive to changes of discount rates and refinancing rates in the short run but this is contrary to 3 month VNIBOR. This can be explained as below: VNIBOR is formed on the base of relation between supply and demand of capital but this is the relation between banks in the market. Specifically, banks with less liquidity will lend from banks with redundancy just in a very short time to solve urgently on due amount, ensure mandatory reserves or loan to keep customers and increase profit. As 1 month VNIBOR is lower than 3 month VNIBOR. Therefore, banks will set their priority to select 1 month VNIBOR than 3 month VNIBOR.

The result of pass-through from money market rates to retail interest rates is represented at Table 5

Table 5. The pass-through from money market rates to retail interest rates

\begin{tabular}{|c|c|c|c|c|c|c|c|c|}
\hline & \multicolumn{4}{|c|}{ IB1 } & \multicolumn{4}{|c|}{ IB3 } \\
\hline & \multicolumn{3}{|c|}{ Short-run } & \multirow{2}{*}{$\frac{\text { Long-run }}{\alpha_{1}}$} & \multicolumn{3}{|c|}{ Short-run } & \multirow{2}{*}{$\frac{\text { Long-run }}{\alpha_{1}}$} \\
\hline & $\beta o$ & $\delta$ & MAL & & $\beta o$ & $\delta$ & MAL & \\
\hline DR & 0,177 & $-0,187$ & 4,401 & 0,767 & 0,252 & $-0,242$ & 3,091 & 0,931 \\
\hline LR & 0,097 & $-0,244$ & 3,701 & 0,694 & 0,159 & $-0,290$ & 2,900 & 0,839 \\
\hline
\end{tabular}

The pass-through from 1 month VNIBOR to deposit rate and lending rate

In the long-run, the degree of passthrough from 1 month VNIBOR to deposit rate and lending rate is respectively high (0.77) and (0.7). That means deposit rate and lending rate will change $0.77 \%, 0.7 \%$ respectively in response to changes $1 \%$ of 1 month VNIBOR. 
This shows that deposit rate and lending rate are relatively sensitive to changes of 1 month VNIBOR in the long run.

In the short-run, the direct pass-through from 1 month VNIBOR to deposit rate and lending rate is very low (0.18) and (0.1). That means deposit rate and lending rate will change $0.18 \%$ and $0.1 \%$ respectively in response to change $1 \%$ of 1 month VNIBOR. Moreover, Adjustment speed to long-run equilibrium is respectively low (-0.19) and (-0.24). MAL shows that it takes about 4 months for deposit rate and lending rate to adjust to long-run equilibrium. So, deposit rate and lending rate is very little sensitive to changes of 1 month VNIBOR in the short-run.

The pass-through from 3 month VNIBOR to deposit rate and lending rate

In the long-run, the degree of passthrough from 3 month VNIBOR to deposit rate and lending rate is very high (0.93) and (0.84) respectively. That means deposit rate and lending rate will change $0.93 \%, 0.84 \%$ respectively in response to changes $1 \%$ of 3 month VNIBOR. This shows that deposit rate and lending rate are extremely sensitive to changes of 3 month VNIBOR in the long run.

In the short-run, the direct pass-through from 3 month VNIBOR to deposit rate and lending rate is very low $(0.25)$ and $(0.16)$. That means deposit rate and lending rate will change respectively $0.25 \%$ and $0.16 \%$ in response to change $1 \%$ of 3 month VNIBOR. Moreover, Adjustment speed to long-run equilibrium is correlatively low (-0.24) and (0.29 ) in turn. MAL shows that it takes about 3 months for deposit rate and lending rate to adjust to long-run equilibrium. So, deposit rate and lending rate is very little sensitive to changes of 3 month VNIBOR in the short-run.

In summary, the pass-through from policy rates through money market rates to retail interest rates in the long-run at commercial banks of Viet Nam is incomplete because the control of activities of commercial banks is not truely effective due to existence of underground agreement as well as lack of transparency in information and policy.

\section{Conclusion}

The paper uses error correction model
(ECM) to estimate interest rate pass-through in Viet Nam. The results show that the passthrough from policy rates through money market rates to retail interest rates in the longrun is incomplete but at high level (0.7-0.93) in the period 07/2004-06/2014.

1 month VNIBOR is very sensitive to changes of discount rates and refinancing rates in the short run but this is contrary to 3 month VNIBOR.

The pass-through from money market rates to retail interest rates is fairly high in the long run but low in the short run. This can be explained as below: there are always lags when the state bank of Vietnam implements monetary policy. So, this lags make the passthrough relatively low in the short-run.

We find that a country with high or complete interest rate pass-through will use interest rate tools to help regulate economy effectively. Therefore, the state bank of Vietnam must have suitable, flexible method and policy in various phases and particular context so that the efficiency of monetary policy through pass-through channel is the highest.

Adjustment speed of interest rate is also slow. Generally, It takes from 3-6 months for various kinds of interest rates to adjust to longrun equilibrium, except 1 month VNIBOR. This is appropriate to actuality of undeveloped financial system with so many problems like Vietnam.

The pass-through is different between various kinds of retail interest rates. Specifically, the pass-through of deposit rate is higher than that of lending rate both in the short term and long term. This can be explained due to a high level from foreign debt of Vietnam.

\section{Limitations \& Suggestions for next research}

The paper has just estimated general pass-through of interest rate, but not gone into depth of other issues: asymmetric interest rate pass-through or estimation of influence of other macroeconomics factors.

Due to data limitation, the paper can't compare the pass-through of particular objects such as: household, enterprises, individuals 
and other interest rate terms.

From these limitations, we suggest that data should be more fully collected with other interest rate terms to implement the research of interest rate pass-through with other terms of market rates and retail interest rates.
Simultaneously, the research of pass-through from policy rates to retail interest rates of firms and individuals \& the research of macroeconomics \& financial banking factors influencing to interest rate pass-through may be needed in next research.

\section{REFERENCES}

Aydin, H, I. (2007). Interest rate pass-through in Turkey. Research and Monetary Policy Department, Working Paper No 07/05. The Central Bank of The Republic of Turkey.[Online] Available:

http://www.tcmb.gov.tr/research/discus/WP0705ENG.pdf

Bernanke, B.S. and Gertler, M. (1995). Inside the black box: the credit chanel of monetary policy transmission. Journal of Economic perspective, 9(4):27-48.

Blot, C. and Labondance, F. (2010). Bank interest rate pass-through in the Eurozone: Monetary policy transmission during the boom and since the financial crash. http://congres.afse.fr/docs/2011/679979blot_labondance_afse.pdf

Bondt, G. D. (2002). Retail bank interest rate pass-through: New evidence from the Euro area level. Working paper No.136, European Central Bank Working Paper Series.

Borio, C., and Fritz, W. (1995). The response of short-term bank lending rates to policy rates: A cross-country perspective. BIS Working Papers no. 27. [Online] Available: www.bis.org/publ/work27.pdf

Cottarelli, C., and Kourelis, A. (1994). Financial structure, bank lending rates, and the transmission mechanism of monetary policy. IMF Staff Papers, 41(4), 587- 623. http://dx.doi.org/10.2307/3867521

De Bondt, G. (2005). Interest rate pass through: Empirical results for the Euro area. German Economic Review, 6: 37-78. http://dx.doi.org/10.1111/j.1465-6485.2005.00121.x

Dinh Thi Thu Hong and Phan Dinh Manh (2013). The efficiency of monetary policy through interest rate pass-through channel. Journal of development and integration.

Donnay, M. and H. Degryse, (2001). Bank lending rate pass-through and differences in the transmission of a single EMU monetary policy, Discussion Paper, Center for Economic Studies, K.U.Leuven. [Online] Available: www.econ.kuleuven.be/ces/discussionpapers/Dps01/Dps0117.pdf

Engle, R. F. and Granger, C.W.J., (1987). Cointergration and Error Correction:Representation, Estimation, and Testing, Econometrics, 55(2):251-276.

Espinosa-Vega M.A. and Rebucci, A. (2003). Retail bank interest rate pass-through and differences in the transmission of a single EMU monetary policy. K.U. Leuven.[Online] Available: www.econ.kuleuven.be/ces/discussionpapers/Dps01/Dps0117.pdf

Heffernan, S.A. (1997). Modelling British interest rate adjustment: An error correction approach. Economica 64, 211-31. 
Hendry, D.F. (1995). Dynamic Econometrics, Oxford University Press, Oxford.

Hofmann, B. (2002). The pass-through of money market rates to business loan rates in the euro area countries. Center for European Integration Studies (ZEI), University of Bonn.

Kleimeier, S. and Sander, H. (2000). Regionalisation versus globalisation in European financial market integration: Evidence from co-integration analyses. Journal of Banking \& Finance, 24(6), 1005-1043. http://dx.doi.org/10.1016/S0378-4266(99)00116-8

Le Viet Hung and Pfau, W. D. (2008). VAR Analysis of the Monetary Transmission Mechanism in Vietnam, Applied Econometrics and International Development.

Lim, G.C. (2001). Bank Interest Rate Adjustments: Are They Asymmetric?. The Economic Record 77(237), pp. 135-147.

Marotta, G. (2009). Structural breaks in the lending interest rate pass-through and the Euro. Economic Modelling, 26: 191-205. http://dx.doi.org/10.1016/j.econmod.2008.06.01

Ming- Hua Liu, Dimitri Margaritis and Alireza Tourani-Rad (2005). Monetary policy transparency and pass-through of retail interest rates. Enterprise and Innovation, Research paper series, Faculty of Bussiness ISSN Number 1176-1997.

Minskin, F. S. (1996). The Channels of Monetary Transmission: Lessons for Monetary Policy, NBER Working Paper.

Mojon, B. (2000). Financial structure and the interest rate channel of ECB monetary policy. Working Paper No 40. [Online] Available:

http://papers.ssrn.com/sol3/papers.cfm?abstract_id=356001

Mozzami, B. (1999). Lending Rate Stickiness and Monetary Policy Transmission: the Case of Canada and the United States. Applied Financial Economics, Vol. 9, 533-538. http://dx.doi.org/10.1080/096031099331989 Niggle, C.J. (1987). A comment on the markup theory of bank loan rates. Journal of Post Keynesian Economics, 9(4), 629-631.

Nguyen Khac Quoc Bao (2014). Research of monetary policy pass-through in Viet Nam. Journal of development and integration.

Roelands, S. (2012). Asymmetric Interest rate Pass-Through from Monetary policy: The role of bank regulation.

http://papers.ssrn.com/so13/papers.cfm?abstract_id=2143451

Toolsema, L., Sturm, J., and Dehaan, J. (2002). Convergence of pass-through frommoney market to lending rates in EMU countries: New evidence. University of Groningen, Centre for Economic Research, Netherlands. CCSO Working Papers. [Online] Available: http://ccso.eldoc.ub.rug.nl/FILES/root/2002/200206/200206.pdf

Tran Ngoc Tho and Nguyen Huu Tuan (2013). Monetary policy pass-through mechanism in Viet Nam: An SVAR model approach. Journal of development and integration.

Ur Rehman, H. (2009). Interest rate pass-through and banking market Integration in ASEAN: A Cross Country Comparison. Degree of Master thesis, University of Malaya. 